Journal of Animal and Feed Sciences, I, 1992, 237-253

\title{
Dietary protein source in the diet and digestibility of fibre fractions in sheep
}

\author{
P. Dakowski \\ The Kielanowski Institute of Animal Physiology and Nutrition, Polish Academy of Sciences \\ 05-110 Jablonna, Poland
}

(Received 26 November 1992; accepted 14 December 1992)

\begin{abstract}
Three experiments were carried out on sheep in which the rate of degradation of dry matter and fibre fractions of dehydrated whole maize plants (DWM) using a nylon bag technique (experiment I), digestibility of the dietary nutrients in the gastro-intestinal tract (experiments II and III) and its particular parts (experiment II) were studied. The animals were fed diets containing DWM and rapeseed oilmeal $(\mathrm{R})$, fish meal $(\mathrm{F})$, a barley-urea preparation $(\mathrm{U})$ or a control diet containing only DWM (C). Diets R, F and U were isonitrogenous and isocaloric. The dietary nitrogen source did not affect ruminal degradability of the maize fibre fractions in sacco (experiment I), however greater digestibility of crude fibre, NDF, ADF and cellulose in diets $R$ and $F$ than in $U$ or $C$ was found (experiment II). Intestinal digestibility of fibre fractions and its ratio to whole tract digestibility were higher in the urea-containing diet than in the remaining diets. Although whole tract digestibility of fibre fractions did not depend on the dietary protein source (experiments II and HI), digestibility of fibre fractions was found to be significantly lower in sheep fed diet $\mathrm{C}$ as compared with those given diets $\mathrm{R}, \mathrm{F}$ or $\mathrm{U}$.
\end{abstract}

KEY WORDS: fibre fractions, nitrogen source, digestibility, sheep

\section{INTRODUCTION}

Roughages with high fibre content are the basic component of diets fed to ruminants, and their digestibility and utilization are determined by the rumen conditions. An important factor affecting the fibre digestibility of these feeds are the nitrogenous compounds included in the diet.

The in vitro experiments of Thomsen (1985) and the in vivo experiments of McAllan and Smith (1983) on digestion of starch and cellulose showed that activity of cellulolytic bacteria is more, than of amylolytic bacteria, dependent on the presence of protein nitrogen. The in vitro digestibility of cellulose (Thomsen, 1985) was lowest when urea was used as the nitrogen source. Maeng et al. (1976) showed that isonitrogenous replacement of urea by a mixture of 18 amino acids increased carbohydrate digestibility and total number of rumen microorganisms. In contrast to in vitro studies, the results of in vivo experiments are not as 
unequivocal. Oldham et al. (1979), McAllan and Smith (1983) and McAllan and Griffith (1987) showed that including in the diets feeds of low ruminal protein degradability resulted in better degradation of dry matter (DM), organic matter (OM) and fibre fractions, whereas Goetsch et al. (1984), Ha et al. (1986) and Zerbini et al. (1988) did not find any effect of the dietary nitrogen source on the digestibility of these components. Fattet and Ørskov (1984) demonstrated in in sacco studies that the digestibility of hay DM incubated in the rumen of sheep, fed a diet containing barley and soya bean meal, was higher than when they were given a barley-urea diet. However, replacing urea with soya bean meal in diets containing fresh forages and maize cobs did not increase the DM or fibre digestibility of these feeds in sheep (Alvarez et al., 1984).

Due to the conflicting results of these studies, a series of experiments was undertaken to determine the effect of the dietary nitrogen source on the digestibility of fibre and its fractions. The objective of the experiments reported here was to determine the ruminal, intestinal and whole tract digestibilities of DM, OM and fibre fractions of DWM by sheep fed alone or supplemented with rapeseed oilmeal, fish meal or urea.

\section{MATERIAL AND METHODS}

Three experiments were carried out on sheep to study the rate of ruminal degradation of DM and fibre fractions of DWM using a nylon bag technique (experiment I), the whole tract digestibility of the studied dietary nutrients (experiments II and III) and their digestibility in particular parts of the gastro-intestinal tract (experiment II).

Experiment $I$ - the first part of this experiment was carried out on 6 Polish Merino rams with a mean liveweight of $54 \mathrm{~kg}$, fitted with rumen cannulae. The animals were fed, in a $3 \times 3 \times 2$ Latin square design, with diets composed of DWM supplemented with rapeseed oilmeal $(R)$, fish meal $(F)$, barley-urea preparation (U) prepared according to Kowalczyk et al. (1983), or a control diet contained only DWM (C). The daily ration, amounted to $2.7 \%$ of body weight, was given in two equal daily portions.

The second part of the experiment was carried out on 4 wethers fitted with rumen cannulae. The wethers, of average weight of $77 \mathrm{~kg}$, were fed the control $\operatorname{diet}(\mathrm{C})$, amounted $2.5 \%$ of body weight, given in equal portions twice a day. The composition of the diets is given in Table 1 . The animals were housed in separate pens with free access to water. After 16 days of feeding each diet DWM were incubated in the rumen of sheep according to the method described by Mehrez and Ørskov (1977). Dacron bags, $11 \times 8 \mathrm{~cm}$ with pore sizes of $53 \times 36$ microns, containing $5 \mathrm{~g}$ of the studied sample were incubated $12,24,36$, and 72 
TABLE 1

Composition and nutrient contents of diets

\begin{tabular}{lrrrrrrrrr}
\hline \multirow{2}{*}{ Components } & \multicolumn{3}{c}{ Experiment I and III } & \multicolumn{5}{c}{ Experiment II } \\
\cline { 2 - 9 } & \multicolumn{1}{c}{$\mathrm{R}$} & $\mathrm{F}$ & $\mathrm{U}$ & $\mathrm{C}$ & $\mathrm{R}$ & $\mathrm{F}$ & $\mathrm{U}$ & $\mathrm{C}$ \\
\hline Dehydrated whole plant maize & 78.8 & 88.4 & 89.7 & 100.0 & 87.6 & 93.1 & 93.1 & 100.0 \\
Rapeseed oilmeal & 21.2 & - & - & - & 12.4 & - & - & - \\
Fish meal & - & 11.6 & - & - & - & 6.9 & - & - \\
Urea & - & - & 10.3 & - & - & - & 6.9 & - \\
\hline Dry matter, \% & 91.4 & 91.9 & 91.9 & 91.7 & 91.8 & 92.0 & 92.2 & 91.9 \\
in DM, \% & & & & & & & & \\
Crude protein & 14.3 & 13.6 & 13.6 & 6.7 & 13.6 & 13.5 & 13.5 & 9.4 \\
Crude fibre & 20.2 & 20.2 & 20.9 & 22.9 & 22.5 & 22.7 & 23.0 & 24.4 \\
$\quad$ NDF & 60.0 & 60.0 & 62.7 & 67.9 & 62.1 & 62.3 & 63.6 & 66.9 \\
ADF & 26.4 & 25.1 & 26.0 & 28.4 & 27.6 & 27.3 & 27.7 & 29.3 \\
ADL & 5.1 & 3.7 & 3.9 & 4.2 & 5.9 & 5.3 & 5.3 & 5.7 \\
Hemicellulose & 33.6 & 34.9 & 36.7 & 39.5 & 34.5 & 34.9 & 35.9 & 37.5 \\
$\quad$ Cellulose & 21.3 & 21.4 & 22.1 & 24.2 & 21.7 & 22.0 & 22.4 & 26.7 \\
Gross energy MJ/kg DM & 18.3 & 18.1 & 18.4 & 17.9 & 18.4 & 18.4 & 18.5 & 18.2 \\
\hline
\end{tabular}

hours. After removal from the rumen the bags were thoroughly washed under running water and dried at a temperature of $60^{\circ} \mathrm{C}$ for 24 hours.

Experiment $I I$ - was conducted on 4 rams aged 10 months with a mean initial weight of $40 \mathrm{~kg}$, fitted with rumen cannulae and simple cannulae of the duodenum and of the ileum. The sheep were fed, in a $4 \times 4$ Latin square design, on diets $\mathrm{R}, \mathrm{F}, \mathrm{U}$ and $\mathrm{C}$ (Table 1 ) as in experiment $\mathrm{I}$, given in two equal daily portions amounting to $2.7 \%$ of body weight. Digesta flow was estimated by adding to the rumen, twice a day after feeding, a cellulose-chromium marker prepared according to Corbett et al. (1960) starting on day 10 after feeding of each diet. Faeces were collected on days 17 and 18. Duodenal and ileal digesta samples were taken every 2 hours on days 20 and 21 of the experiment. The individual samples were pooled and stored at $-18^{\circ} \mathrm{C}$ until analysis. On the same days ruminal fluid was sampled before and 2 and 4 hours after feeding.

Experiment $I I I$ - was carried out on 6 rams with a mean initial liveweight of 51 $\mathrm{kg}$. The animals were fed diets $\mathrm{R}, \mathrm{F}$ und $\mathrm{U}$, in a $3 \times 3 \times 2$ Latin square design, as in experiment I (Table 1). After 16 days of feeding, faeces were collected for 6 days into bags. Faeces were sampled three times a day from the bags and stored at $-18^{\circ} \mathrm{C}$ until analysis. 
Degradation of rapeseed oilmeal and fish meal protein was determined according to Mehrez and Ørskov (1977) on 3 adult wethers weighing about $70 \mathrm{~kg}$ and fed a standard diet of meadow hay and barley grain.

\section{Analyses}

The basic analyses of feed, duodenal, ileal and faecal samples were carried out using standard methods. Neutral detergent fibre (NDF), acid detergent fibre (ADF) and acid detergent lignin (ADL) in feeds, residual remaining after incubation of the samples in the rumen and in freeze-dried duodenal digesta and faecal samples were determined by the method of Van Soest and Wine (1967) and Van Soest (1973) using a Fibertec M (Tecator) apparatus. The $\mathrm{Cr}_{2} \mathrm{O}_{3}$ content was determined according to the method of Kimura and Miller (1957). The $\mathrm{pH}$ of the ruminal fluid was determined potentiometrically, $\mathrm{N}-\mathrm{NH}_{3}$ by the method of Conway (1954) and volatile fatty acids (VFA) by the procedure of Ziołecki and Kwiatkowska (1973).

\section{Statistical analyses}

The results were subjected to least-square variance analysis, the significance of differences was calculated by a multiple range test. In experiment $I$ the significance of differences among diets was calculated by Student's t-test.

\section{RESULTS}

The diets, differing in their nitrogen source $(\mathrm{R}, \mathrm{F}, \mathrm{U})$, were isonitrogenous and contained, on average, $13.8 \%$ crude protein $(\mathrm{CP})(\mathrm{N} \times 6.25)$ in a $\mathrm{DM}$ in experiments I and III, and $13.5 \%$ in experiment II (Table 1). The gross energy content of all of the diets was similar and averaged $18.3 \mathrm{MJ} / \mathrm{kg}$ DM. Diet C (control) contained $6.7 \%$ crude protein in DM in experiment $\mathrm{I}$ and $9.4 \%$ in experiment II; this variation was due to differences in the quality of the DWM purchased for the experiments in the different years. The animals consumed all of the given rations.

The rapeseed and fish meals differed considerably in their ruminal protein degradability. Although the amount of protein removed from both feeds after 2 hours of incubation in the rumen was similar and equalled $30 \%$, after 48 hours it differed significantly and equalled $90 \%$ for rapeseed oilmeal and $43 \%$ for fish meal (Fig. 1). Both, constants $\mathrm{a}, \mathrm{b}$ and $\mathrm{c}$ and the effective ruminal protein degradability differed significantly between the two feeds. The effective ruminal protein degradability calculated according to Ørskov and McDonald (1979) was much higher for rapeseed oilmeal than for fish meal (Table 2). 


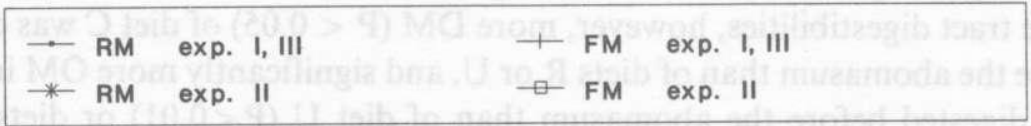

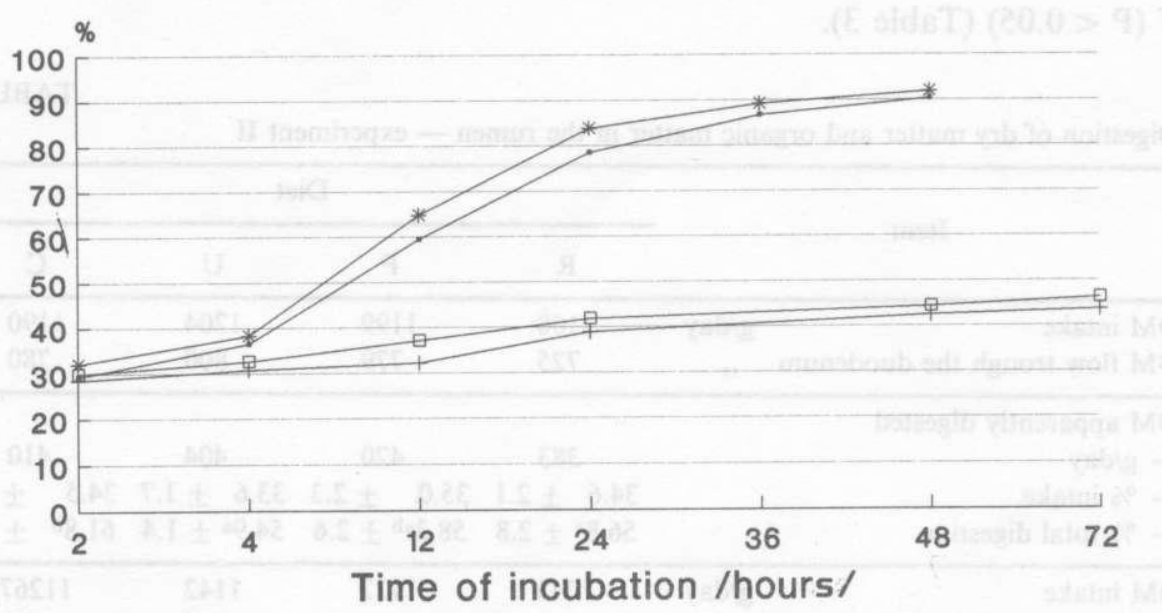

Figure 1. Degradability of rapeseed oilmeal (RM) and fish meal (FM) protein incubated in the rumen

TABLE 2

Constant values a, b, c and effective degradability (ED) of rapeseed meal and fish meal protein (exp. I, II, III) and of dehydrated whole plant maize dry matter (exp. I)

\begin{tabular}{lllll}
\hline & a & b & c & ED \\
\hline $\begin{array}{l}\text { Rapeseed oilmeal } \\
\text { exp. I, III }\end{array}$ & 20 & 74 & 0.064 & 58 \\
$\quad$ exp. II & 20 & 74 & 0.078 & 62 \\
Fish meal & & & & \\
$\quad$ exp. I, III & 34 & 18 & 0.038 & 34 \\
$\quad$ exp. II & 28 & 18 & 0.058 & 37 \\
\hline Dehydrated whole & & & & \\
plant maize & & & & \\
diet R & 29 & 55 & 0.025 & 44 \\
diet F & 26 & 55 & 0.027 & 43 \\
diet U & 30 & 53 & 0.025 & 45 \\
\hline
\end{tabular}

In experiment $\mathrm{I}$, in sacco ruminal degradation of DM of DWM determined after different times of incubation, did not depend on the type of diet. The diets also did not affect the effective degradability $(43-45 \%)$ of DM in the rumen (Table 2). The degradabilities of dietary DM and OM before the abomasum and 
amount passing into the duodenum (experiment II) were similar. In relation to whole tract digestibilities, however, more DM $(P<0.05)$ of diet $C$ was digested before the abomasum than of diets $\mathrm{R}$ or $\mathrm{U}$, and significantly more $\mathrm{OM}$ in diet $\mathrm{C}$ were digested before the abomasum than of $\operatorname{diet} \mathrm{U}(\mathrm{P}<0.01)$ or diets $\mathrm{R}$ and $\mathrm{F}(\mathrm{P}<0.05)($ Table 3$)$.

TABLE 3

Digestion of dry matter and organic matter in the rumen - experiment II

\begin{tabular}{|c|c|c|c|c|c|}
\hline \multirow{2}{*}{ Item } & & \multicolumn{4}{|c|}{ Diet } \\
\hline & & $\mathbf{R}$ & $\mathrm{F}$ & $\mathrm{U}$ & C \\
\hline DM intake & $\mathrm{g} /$ day & 1108 & 1199 & 1204 & 1190 \\
\hline DM flow trough the duodenum & ", & 725 & 779 & 800 & 780 \\
\hline \multicolumn{6}{|l|}{ DM apparently digested } \\
\hline - g/day & & 383 & 420 & 404 & 410 \\
\hline - \% intake & & $34.6 \pm 2.1$ & $35.0 \pm 2.3$ & $33.6 \pm 1.7$ & $34.5 \pm 1.1$ \\
\hline - \% total digestion & & $56.8^{a} \pm 2.8$ & $58.3^{\mathrm{ab}} \pm 2.6$ & $54.9^{\mathrm{a}} \pm 1.4$ & $61.8^{\mathrm{b}} \pm 2.0$ \\
\hline OM intake & $\mathrm{g} /$ day & 1043 & 1122 & 1142 & 11267 \\
\hline OM flow trough the duodenum & , & 606 & 663 & 676 & 655 \\
\hline \multicolumn{6}{|l|}{ OM apparently digested } \\
\hline$-\mathrm{g} /$ day & & 437 & 459 & 466 & 471 \\
\hline$-\%$ intake & & $41.9 \pm 1.9$ & $40.9 \pm 2.3$ & $40.8 \pm 2.5$ & $41.8 \pm 1.3$ \\
\hline - \% total digestion & & $66.2^{\mathrm{a}} \pm 2.1$ & $65.2^{\mathrm{a}} \pm 1.9$ & $64.4^{\mathrm{A}} \pm 3.3$ & $72.4^{\mathrm{Bb}} \pm 2.6$ \\
\hline
\end{tabular}

$\mathrm{A}, \mathrm{B}-\mathrm{P}<0.01 ; \mathrm{a}, \mathrm{b}-\mathrm{P}<0.05$

The losses of fibre fractions as determined in sacco (experiment I) during the particular periods of incubation were similar when feeding diets $R, F$ and $U$ (Table 4). The digestibility of fibre fractions, as calculated on the basis of its intake and outflow from the abomasum, was found to be influenced by the dietary nitrogen source (experiment II). The digestibilities of fibre fractions, NDF, ADF and cellulose were greater $(P<0.05)$ when feeding diets $R$ and $F$ than $\mathrm{U}$ or $\mathrm{C}$. The preabomasal digestibility of fibre fractions in comparison with their whole tract digestibility were lower in diet $\mathrm{U}$ than in diets $\mathrm{R}, \mathrm{F}$ or $\mathrm{C}$ (Table 5).

The $\mathrm{pH}$ of the rumen content was not dependent on the diet and averaged 6.94 before and 6.43 and 6.52 two and four hours after feeding, respectively (Table 6). The ruminal $\mathrm{N}-\mathrm{NH}_{3}$ concentration on diets $\mathrm{R}$ and $\mathrm{F}$ was similar (Table 6). However, when diet $\mathrm{C}$ was given, the ruminal $\mathrm{N}-\mathrm{NH}_{3}$ concentration was lower $(\mathrm{P}<0.05)$ than on the remaining diets. The $\mathrm{N}-\mathrm{NH}_{3}$ concentration in the rumen of sheep fed diet $\mathrm{U}$ was lower before feeding and higher 2 and 4 hours after feeding in comparison with the remaining diets $(\mathrm{P}<0.01)$. 
TABLE 4

Fibre fractions degradability in the rumen $(\%)$ - experiment I

\begin{tabular}{|c|c|c|c|c|c|c|}
\hline \multirow{2}{*}{$\begin{array}{l}\text { Fibre } \\
\text { fractions }\end{array}$} & \multirow{2}{*}{ Diet } & \multicolumn{5}{|c|}{ Incubation time (hour) } \\
\hline & & 12 & 24 & 36 & 48 & 72 \\
\hline \multirow{4}{*}{ Crude fibre } & $\mathbf{R}$ & $13.4 \pm 5.70$ & $28.7 \pm 6.87$ & $39.2 \pm 8.89$ & $44.7 \pm 7.68$ & $57.7 \pm 5.60$ \\
\hline & $\mathbf{F}$ & $14.8^{\mathrm{a}} \pm 2.74$ & $23.8^{\mathrm{A}} \pm 3.85$ & $37.6^{\mathrm{A}} \pm 3.81$ & $47.6^{\mathrm{A}} \pm 4.86$ & $56.6^{\mathrm{A}} \pm 4.63$ \\
\hline & $\mathrm{U}$ & $17.5^{\mathrm{a}} \pm 5.65$ & $28.1^{\mathrm{A}} \pm 4.07$ & $40.8^{\mathrm{A}} \pm 5.49$ & $47.2^{\mathrm{A}} \pm 5.64$ & $59.0^{\mathrm{A}} \pm 5.11$ \\
\hline & $\mathrm{C}$ & $10.4 \pm 2.18$ & $15.5 \pm 2.19$ & $29.1 \pm 3.58$ & $36.5 \pm 2.12$ & $46.3 \pm 3.20$ \\
\hline \multirow{4}{*}{ NDF } & $\mathrm{R}$ & $32.3^{\mathrm{a}} \pm 3.32$ & $44.7^{\mathrm{a}} \pm 5.29$ & $53.3^{\mathrm{a}} \pm 4.03$ & $58.0^{\mathrm{a}} \pm 5.23$ & $68.6^{\mathrm{A}} \pm 3.30$ \\
\hline & $\mathbf{F}$ & $32.0^{\mathrm{A}} \pm 1.37$ & $41.0^{\mathrm{a}} \pm 2.70$ & $53.4^{\mathrm{a}} \pm 4.08$ & $59.6^{\mathrm{A}} \pm 3.26$ & $66.9^{\mathrm{A}} \pm 3.55$ \\
\hline & $\mathbf{U}$ & $32.9^{\mathrm{A}} \pm 2.99$ & $43.0^{\mathrm{A}} \pm 3.47$ & $54.4^{a} \pm 4.79$ & $58.1^{\mathrm{a}} \pm 4.77$ & $68.6^{\mathrm{A}} \pm 3.07$ \\
\hline & $\mathrm{C}$ & $27.0 \pm 2.02$ & $36.2 \pm 1.01$ & $46.7 \pm 1.96$ & $50.7 \pm 2.16$ & $58.2 \pm 1.92$ \\
\hline \multirow{4}{*}{ ADF } & $\mathbf{R}$ & $15.4 \pm 3.83$ & $29.8 \pm 7.78$ & $37.9 \pm 5.79$ & $42.7 \pm 5.81$ & $57.3^{\mathrm{A}} \pm 4.19$ \\
\hline & $\mathbf{F}$ & $16.7 \pm 3.15$ & $26.2 \pm 3.23$ & $37.4 \pm 3.91$ & $45.9^{\mathrm{A}} \pm 3.50$ & $54.5^{\mathrm{a}} \pm 4.96$ \\
\hline & $\mathrm{U}$ & $18.2^{\mathrm{A}} \pm 2.16$ & $28.6 \pm 5.22$ & $40.8^{\mathrm{a}} \pm 6.21$ & $42.9 \pm 6.23$ & $57.4^{A} \pm 4.20$ \\
\hline & $\mathrm{C}$ & $12.9 \pm 2.51$ & $22.6 \pm 0.84$ & $32.6 \pm 2.58$ & $36.0 \pm 3.01$ & $45.8 \pm 2.43$ \\
\hline \multirow{4}{*}{ ADL } & $\mathbf{R}$ & $6.0 \pm 3.73$ & $15.2 \pm 5.99$ & $14.4 \pm 8.89$ & $14.6 \pm 7.06$ & $27.5 \pm 4.41$ \\
\hline & $\mathrm{F}$ & $4.4 \pm 3.68$ & $12.3 \pm 3.02$ & $18.0 \pm 5.53$ & $16.1^{\mathrm{a}} \pm 3.80$ & $23.2 \pm 6.38$ \\
\hline & $\mathrm{U}$ & $4.7 \pm 4.74$ & $14.8^{\mathrm{A}} \pm 2.40$ & $18.7^{\mathrm{A}} \pm 4.50$ & $14.3^{a} \pm 4.58$ & $25.5^{a} \pm 5.77$ \\
\hline & $\mathrm{C}$ & $2.9 \pm 1.93$ & $8.5 \pm 1.92$ & $10.4 \pm 2.79$ & $11.3 \pm 2.55$ & $16.2 \pm 4.11$ \\
\hline \multirow{4}{*}{ Hemicellulose } & $\mathbf{R}$ & $44.5^{\mathrm{A}} \pm 3.69$ & $55.4^{\mathrm{A}} \pm 3.84$ & $64.4^{\mathrm{A}} \pm 4.04$ & $69.1^{\mathrm{a}} \pm 5.49$ & $76.8^{\mathrm{A}} \pm 3.06$ \\
\hline & $F$ & $43.1^{\mathrm{A}} \pm 2.32$ & $51.3^{a} \pm 3.30$ & $64.0^{a} \pm 4.75$ & $69.5^{\mathrm{A}} \pm 3.54$ & $75.8^{\mathrm{A}} \pm 2.56$ \\
\hline & $\mathrm{U}$ & $43.5^{a} \pm 3.74$ & $53.5^{A} \pm 2.54$ & $64.2^{\mathrm{a}} \pm 4.49$ & $69.0^{A} \pm 4.11$ & $76.6^{\mathrm{A}} \pm 2.35$ \\
\hline & $\mathrm{C}$ & $37.0 \pm 1.72$ & $46.0 \pm 1.76$ & $56.8 \pm 2.18$ & $61.3 \pm 2.00$ & $67.0 \pm 1.90$ \\
\hline \multirow{4}{*}{ Cellulose } & $\mathbf{R}$ & $17.0 \pm 3.99$ & $29.0 \pm 9.83$ & $42.0 \pm 6.40$ & $47.5 \pm 5.81$ & $62.5^{A} \pm 4.40$ \\
\hline & $\mathrm{F}$ & $18.8 \pm 3.78$ & $29.0^{\mathrm{a}} \pm 2.79$ & $40.8 \pm 4.62$ & $51.1^{\mathrm{A}} \pm 4.26$ & $59.9^{\mathrm{A}} \pm 4.83$ \\
\hline & $\mathrm{C}$ & $20.6^{\mathrm{A}} \pm 2.73$ & $31.1 \pm 6.23$ & $45.0 \pm 7.27$ & $47.8 \pm 6.83$ & $62.9^{A} \pm 4.00$ \\
\hline & $\mathrm{U}$ & $14.6 \pm 2.65$ & $25.0 \pm 2.47$ & $36.3 \pm 2.78$ & $40.2 \pm 3.40$ & $50.9 \pm 2.14$ \\
\hline
\end{tabular}

Difference between diet $\mathrm{R}, \mathrm{F}$ or $\mathrm{U}$ and $\operatorname{diet} \mathrm{C}: \mathrm{A}-\mathrm{P}<0.01 ; \mathrm{a}-\mathrm{P}<0.05$

The type of diet did not significantly affect the acetic, propionic or butyric acid concentrations in ruminal liquid before or 2 and 4 hours after feeding, nor that of valeric acid before or 2 hours after feeding. However, a significantly higher valeric acid concentration was found 4 hours after feeding diets $R$ and $U$ as compared with this value for diets $\mathrm{F}$ and $\mathrm{C}$. 
Digestion of fibre fractions in the rumen - experiment II

\begin{tabular}{|c|c|c|c|c|c|c|c|c|c|c|}
\hline \multirow{2}{*}{$\begin{array}{c}\text { Fibre fraction } \\
\text { digestibility }\end{array}$} & \multicolumn{10}{|c|}{ Diet } \\
\hline & $\mathbf{R}$ & 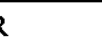 & & $\mathbf{F}$ & & & $\mathrm{U}$ & & $\mathrm{C}$ & \\
\hline \multicolumn{11}{|l|}{ Crude fibre } \\
\hline$-\%$ intake & $45.8^{\mathrm{Aa}}$ & \pm 1.1 & $46.7^{\mathrm{Aa}}$ & \pm & 3.5 & $42.6^{b}$ & \pm 1.4 & $38.6^{\mathrm{Bc}}$ & \pm & 1.92 \\
\hline - $\%$ total digestion & $83.8^{\mathrm{a}}$ & \pm 4.4 & $85.8^{\mathrm{a}}$ & \pm & 2.7 & $77.1^{\mathrm{b}}$ & \pm 5.3 & $81.2^{\mathrm{ab}}$ & \pm & 6.77 \\
\hline \multicolumn{11}{|l|}{ NDF } \\
\hline - $\%$ intake & $49.4^{\mathrm{ab}}$ & \pm 2.3 & $51.6^{\mathrm{a}}$ & \pm & 2.9 & $46.9^{b}$ & \pm 2.5 & $47.2^{\mathrm{b}}$ & \pm & 0.8 \\
\hline - $\%$ total digestion & $79.1^{\mathrm{a}}$ & \pm 4.1 & $81.6^{\mathrm{A}}$ & \pm & 3.2 & $74.3^{\mathrm{Bb}}$ & \pm 4.7 & $81.4^{\mathrm{A}}$ & \pm & 2.2 \\
\hline \multicolumn{11}{|l|}{ ADF } \\
\hline - $\%$ intake & $40.3^{a}$ & \pm 1.7 & $41.3^{\mathrm{ac}}$ & \pm & 3.7 & $37.1^{b}$ & \pm 2.0 & $37.8^{\mathrm{ab}}$ & \pm & 1.9 \\
\hline - $\%$ total digestion & $79.4^{\mathrm{a}}$ & \pm 3.7 & $79.0^{\mathrm{a}}$ & \pm & 3.2 & $71.3^{\mathrm{Ab}}$ & \pm 5.9 & $83.5^{\mathrm{B}}$ & \pm & 2.9 \\
\hline \multicolumn{11}{|l|}{ ADL } \\
\hline - $\%$ intake & 15.3 & \pm 5.0 & 14.6 & \pm & 2.3 & 10.4 & \pm 2.0 & 14.1 & & 0.8 \\
\hline - $\%$ total digestion & 118.0 & \pm 33.9 & 95.8 & \pm & 24.4 & 81.7 & \pm 6.2 & 143.9 & & 32.9 \\
\hline \multicolumn{11}{|l|}{ Hemicellulose } \\
\hline - $\%$ intake & 56.5 & \pm 3.6 & 59.7 & \pm & 2.5 & 54.4 & \pm 3.5 & 54.8 & \pm & 2.0 \\
\hline - $\%$ total digestion & $78.8^{\mathrm{ab}}$ & \pm 5.1 & $83.3^{\mathrm{A}}$ & \pm & 3.5 & $76.1^{\mathrm{Ba}}$ & \pm 4.5 & $80.6^{b}$ & \pm & 2.4 \\
\hline \multicolumn{11}{|l|}{ Cellulose } \\
\hline - $\%$ intake & 46.7 & \pm 3.1 & 47.7 & \pm & 4.9 & 43.3 & \pm 2.2 & 43.3 & \pm & 2.2 \\
\hline - $\%$ total digestion & $76.2^{\mathrm{ab}}=$ & \pm 5.6 & $77.8^{a}$ & \pm & 4.6 & $70.3^{b}$ & \pm 5.9 & $80.3^{\mathrm{a}}$ & \pm & 2.4 \\
\hline
\end{tabular}

$\mathrm{A}, \mathrm{B}-\mathrm{P}<0.01 ; \mathrm{a}, \mathrm{b}, \mathrm{c}-\mathrm{P}<0.05$

TABLE 6

$\mathrm{pH}$ and $\mathrm{NH}_{3}-\mathrm{N}$ concentration $(\mathrm{mg} / 100 \mathrm{ml})$ in rumen liquid content - experiment II

\begin{tabular}{|c|c|c|c|}
\hline \multirow{2}{*}{ Diet } & \multicolumn{3}{|c|}{ Time } \\
\hline & $\begin{array}{l}\text { before } \\
\text { feeding }\end{array}$ & $\begin{array}{l}2 \mathrm{~h} \text { after } \\
\text { feeding }\end{array}$ & $\begin{array}{l}4 \mathrm{~h} \text { after } \\
\text { feeding }\end{array}$ \\
\hline & \multicolumn{3}{|c|}{$\mathrm{pH}$} \\
\hline $\mathbf{R}$ & $6.96 \pm 0.13$ & $6.31 \pm 0.17$ & $6.54 \pm 0.05$ \\
\hline $\mathrm{F}$ & $7.00 \pm 0.07$ & $6.43 \pm 0.18$ & $6.56 \pm 0.16$ \\
\hline $\mathrm{U}$ & $6.89 \pm 0.16$ & $6.54 \pm 0.20$ & $6.48 \pm 0.21$ \\
\hline \multirow[t]{2}{*}{$\mathrm{C}$} & $6.90 \pm 0.13$ & $6.44 \pm 0.16$ & $6.62 \pm 0.06$ \\
\hline & \multicolumn{3}{|c|}{$\mathrm{NH}_{3}-\mathrm{N}$} \\
\hline $\mathbf{R}$ & $14.08^{\mathrm{A}} \pm 1.07$ & $15.03^{\mathrm{A}} \pm 1.43$ & $8.16^{\mathrm{Aa}} \pm 1.92$ \\
\hline $\mathbf{F}$ & $13.56^{\wedge} \pm 0.84$ & $14.42^{\mathrm{A}} \pm 0.67$ & $7.81^{\mathrm{Aa}} \pm 1.79$ \\
\hline $\mathrm{U}$ & $10.58^{\mathrm{B}} \pm 1.65$ & $28.73^{B} \pm 3.32$ & $16.17^{\mathrm{B}} \pm 3.25$ \\
\hline $\mathrm{C}$ & $6.49^{C} \pm 1.56$ & $10.53^{\mathrm{C}} \pm 1.36$ & $3.64^{\mathrm{Ab}} \pm 0.41$ \\
\hline
\end{tabular}

A, B, C $-\mathrm{P}<0.01 ; \mathrm{a}, \mathrm{b}-\mathrm{P}<0.05$ 
Intestinal DM digestibility was lowest in diets $\mathrm{C}$ and $\mathrm{F}$ (Fig. 2). Digestibility of $\mathrm{DM}$ of diet $\mathrm{C}$ was significantly $(\mathrm{P}<0.05)$ lower than diets $\mathrm{R}$ or $\mathrm{U}$, of $\operatorname{diet} \mathrm{F}$ significantly $(\mathrm{P}<0.05)$ lower than diet $\mathrm{R}$. Significantly lower $\mathrm{OM}$ digestibility was also found for diet $\mathrm{C}$ than $\operatorname{diets} \mathrm{R}(\mathrm{P}<0.01)$ and $\mathrm{U}(\mathrm{P}<0.05)$. The proportions in which DM and OM were digested in the small intestine in relation to whole tract digestibility were similar for all of the diets.

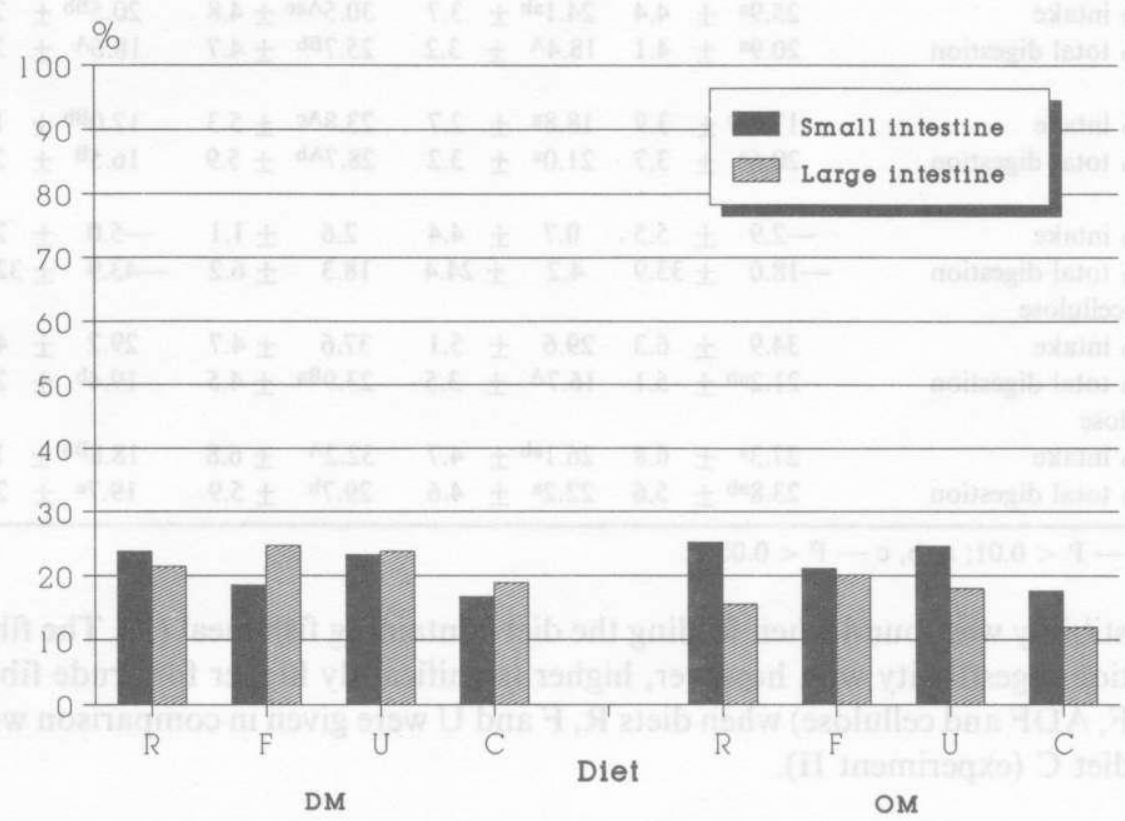

Figure 2. DM and OM digestibility in the small and large intestine - experiment II

The intestinal digestibility of fibre fractions and its ratio to whole tract fibre digestibility were higher when feeding the urea-containing diet than the remaining ones. It was also found that the digestibilities of NDF, ADF and cellulose of diet $\mathrm{C}$ were significantly lower $(\mathrm{P}<0.05)$ than of diets $\mathrm{R}, \mathrm{F}$ and $\mathrm{U}$ (Table 7).

The source of dietary nitrogen did not have a significant effect on the apparent digestibility of DM or OM of diets R, F or U, both in experiments III and II. The digestibility of DM and OM of diet C in experiment II was significantly lower $(\mathrm{P}<0.05)$ than in the remaining diets and equalled 55.7 and $57.8 \%$, respectively (Table 8).

Experimental diets, differing in their nitrogen source, did not affect the whole tract digestibility of fibre fractions, although in experiment II a slightly higher 
Digestion of fibre fractions in the intestine - experiment II

\begin{tabular}{|c|c|c|c|c|c|c|c|}
\hline \multirow{2}{*}{$\begin{array}{l}\text { Fibre fraction } \\
\text { digestion }\end{array}$} & \multicolumn{7}{|c|}{ Diet } \\
\hline & $\mathbf{R}$ & \multicolumn{3}{|c|}{$\mathrm{F}$} & \multicolumn{2}{|c|}{$\mathrm{U}$} & $\mathrm{C}$ \\
\hline \multicolumn{8}{|l|}{ Crude fibre } \\
\hline - $\%$ intake & $16.3 \pm 5.0$ & 14.5 & \pm 2 & 2.0 & 22.0 & \pm 5.7 & $14.6 \pm 5.4$ \\
\hline - $\%$ total digestion & $16.2^{\mathrm{a}} \pm 4.4$ & $14.2^{\mathrm{a}}$ & \pm 2 & 2.7 & $22.9^{\mathrm{b}}$ & \pm 5.3 & $18.8^{\mathrm{ab}} \pm 6.8$ \\
\hline \multicolumn{8}{|l|}{ NDF } \\
\hline$-\%$ intake & $25.9^{\mathrm{a}} \pm 4.4$ & $24.1^{\mathrm{ab}}$ & \pm 3 & 3.7 & $30.5^{\mathrm{Aac}}$ & \pm 4.8 & $20.5^{\mathrm{Bb}} \pm 2.6$ \\
\hline - $\%$ total digestion & $20.9^{\mathrm{a}} \pm 4.1$ & $18.4^{\mathrm{A}}$ & \pm 3 & 3.2 & $25.7^{8 b}$ & \pm 4.7 & $18.6^{\mathrm{A}} \pm 2.2$ \\
\hline \multicolumn{8}{|l|}{$\mathrm{ADF}$} \\
\hline — $\%$ intake & $17.6^{\mathrm{ac}} \pm 3.9$ & $18.8^{\mathrm{a}}$ & \pm 2 & 2.7 & $23.8^{\mathrm{Ac}}$ & \pm 5.3 & $12.0^{\mathrm{Bb}} \pm 1.7$ \\
\hline - \% total digestion & $20.6^{\mathrm{a}} \pm 3.7$ & $21.0^{\mathrm{a}}$ & \pm 3 & 3.2 & $28.7^{\mathrm{Ab}}$ & \pm 5.9 & $16.5^{\mathrm{B}} \pm 2.9$ \\
\hline \multicolumn{8}{|l|}{ ADL } \\
\hline - \% intake & $-2.9 \pm 5.5$ & 0.7 & \pm 4 & 4.4 & 2.6 & \pm 1.1 & $-5.0 \pm 2.6$ \\
\hline - $\%$ total digestion & $-18.0 \pm 33.9$ & 4.2 & \pm 24 & 24.4 & 18.3 & \pm 6.2 & $-43.9 \pm 32.9$ \\
\hline \multicolumn{8}{|l|}{ Hemicellulose } \\
\hline - $\%$ intake & $34.9 \pm 6.3$ & 29.6 & \pm 5 & 5.1 & 37.6 & \pm 4.7 & $29.2 \pm 4.3$ \\
\hline - $\%$ total digestion & $21.2^{\mathrm{ab}} \pm 5.1$ & $16.7^{\mathrm{A}}$ & \pm 3 & 3.5 & $23.9^{\mathrm{Ba}}$ & \pm 4.5 & $19.4^{b} \pm 2.4$ \\
\hline \multicolumn{8}{|l|}{ Cellulose } \\
\hline - $\%$ intake & $27.3^{a} \pm 6.8$ & $26.1^{\mathrm{ab}}$ & \pm 4 & 4.7 & $32.2^{\mathrm{A}}$ & \pm 6.8 & $18.8^{\mathrm{Bb}} \pm 1.4$ \\
\hline - $\%$ total digestion & $23.8^{\mathrm{ab}} \pm 5.6$ & $22.2^{\mathrm{a}}$ & \pm 4 & 4.6 & $29.7^{\mathrm{b}}$ & \pm 5.9 & $19.7^{\mathrm{a}} \pm 2.4$ \\
\hline
\end{tabular}

$\mathrm{A}, \mathrm{B}-\mathrm{P}<0.01 ; \mathrm{a}, \mathrm{b}, \mathrm{c}-\mathrm{P}<0.05$

digestibility was found when feeding the diet containing fish meal $(F)$. The fibre fraction digestibility was, however, higher (significantly higher for crude fibre, NDF, ADF and cellulose) when diets $R, F$ and $U$ were given in comparison with the diet $\mathrm{C}$ (experiment II).

\section{DISCUSSION}

\section{Ruminal digestion}

Fermentation in the rumen, including fibre digestibility, is dependent on, among others, the conditions prevailing in the rumen. Parameters characterizing these conditions are $\mathrm{pH}$ and the concentration and proportions of VFA. Reduction on the cellulolytic activity of bacteria occurs at $\mathrm{pH}$ below 6.0 (Mould et al., 1983/1984; Hoover et al., 1984). In experiment II, the lowest ruminal pH measured 2 hours after feeding equalled 6.4 , which indicates that all of the diets sustained favourable conditions for ruminal carbohydrate fermentation. The proportion of acetic, propionic and butyric acids equalled on average 66:21:13, which means that acetic fermentation was occurring in the rumen and reflects the composition of the diets whose major component was DWM. 
崫

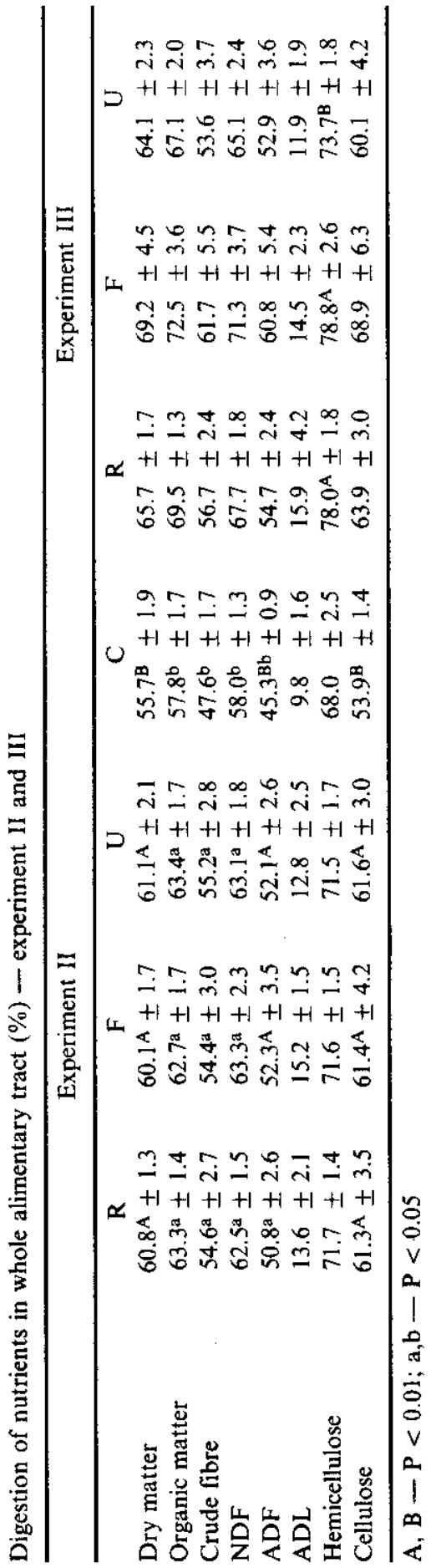


Differences in the type and level of nitrogen compounds in the diets did not affect the ruminal digestibility of DM or OM in the studied diets (experiment II), which is in agreement with studies carried out on dairy cows by Goetsch et al. (1984). These authors using isonitrogenous diets containing urea, casein or soya bean meal or a low protein diet, did not find differences in the digestibility of OM of these diets.

In spite of the lack of differences in the digestibilities of DM and OM, the ruminal digestibility of crude fibre in $\operatorname{diet} \mathrm{C}$ was significantly lower than in the remaining diets, which could have been caused by the lower protein content in that diet and, as a consequence, the low ammonia concentration in the rumen. It equalled $3.64 \mathrm{mg} / 100 \mathrm{ml}$ ruminal fluid and was lower than the minimum believed as optimal for bacterial protein synthesis (Satter and Slyter, 1974; Roffler et al., 1976). The low ruminal ammonia level could also have been the reason of the lower degradability of the maize fibre incubated in the rumen (experiment I).

In a similar manner may be explain the lower digestibility of fibre fractions when diet $\mathrm{U}$ was fed than when the isonitrogenous diets $\mathrm{R}$ and $\mathrm{F}$ were given. When sheep were fed diet $\mathrm{U}$, large fluctuations in the ruminal $\mathrm{N}-\mathrm{NH}_{3}$ concentration were observed, which indicates that periods when the nitrogen concentrations could limit the growth of microorganisms may occur (Coppock et al., 1976; Madsen ad Hvelplund, 1988) and, as a consequence, limit the digestion of fibre. However, in those studies in which animals were fed hourly in order to achieve steady conditions in the rumen, higher digestibilities of DM, OM and cellulose of a diet containing soya bean meal over one containing urea were found, in spite of the fact that the level of ammonia nitrogen in the rumen content was higher when the urea-containing diet was given (Kropp et al., 1977a).

McAllan and Smith (1983) studied the effect of inclusion of urea or fish meal to diets containing flaked corn, tapioca and barley straw on the digestibility of mannose, galactose, arabinose, xylose and beta-glucose in the preabomasum. These authors did not find any effect of the dietary nitrogen source on the digestibility of OM, but they did demonstrate a slightly higher digestibility of all of the above-mentioned sugars in the diet containing fish meal than in the urea and control diets.

The digestibility of fibre fractions in diets containing rapeseed oilmeal and fish meal, which differed by their ruminal protein degradability, was similar (Table 5). This result is in disagreement with the results of McAllan and Griffith (1987). They demonstrated higher digestibility of NDF in the rumen of steers fed diets containing protein with a low ruminal degradability. McAllan (1991) also found increased cellulose and hemicellulose digestibility in the rumen of steers fed a diet containing fish meal and urea than when given a diet supplemented only with urea. 
In spite of the fact that the main source of nitrogen for ruminal bacteria is ammonia, amino acids play an important role in their growth. The amino acid requirement of cellulolytic bacteria is mainly related to their need for branched-chain volatile fatty acids: isobutyric, 2-methylobutyric, isovaleric and for valeric acid (Andries et al., 1987). In experiment II, the higher digestibility of fibre fractions in diets $R$ and $F$ than in $C$ and $U$ could have been related to the higher concentration of isobutyric acid before and 2 hours after feeding. In the studies of Robinson and Sniffen (1983) the digestibility of hemicellulose in the rumen of cows who were given branched-chain volatile fatty acids was higher. Similarly, Hume (1970) demonstrated that the digestibility of OM in the rumen was higher when isoacids were administered, although the total digestibility in the digestive tract did not change.

The differences in the digestibilities of fibre fractions of the diets differing in their nitrogen source in the preabomasal parts of the stomach (experiment II) were not confirmed by in sacco experiment (I). This is difficult to explain and indicate that the results of experiments on feed digestibility carried out using the in sacco technique are not always in agreement with the results obtained in balance trials.

\section{Intestinal digestion}

The fermentation which occurs in the large intestine depends on numerous factors, hence the differences in fibre fraction digestibilities may be notable. Hoover (1978) reports that the digestibility of cellulose in the large intestine of sheep ranges from 18 to $50 \%$, of hemicellulose from 2.5 to $46 \%$, which amounts to $18-27$ and $30-40 \%$ whole tract digestibility, respectively. The digestibility of cellulose and hemicellulose in the large intestine (experiment II) ranged from about 19 to 32 and from 29 to $38 \%$, respectively, which equalled 20 to 30 and 17 to $24 \%$ of total digestibility, which is in argeement with the data of Hoover (1978).

The amount of fibre potentially digestible in the large intestine and which has not been digested in the rumen, has a direct effect on the digestibility of fibre in the large intestine (Hoover, 1978). Many studies have shown that fibre digestibility in the rumen decreases while its digestibility in the large intestine increases when plants cut at late stages of growth with large amount of low digestibility fibre (Beever et al., 1972), ground or pelleted feeds (Thomson et al., 1969; Beever et al., 1972; Thomson et al., 1972) as well as rations containing large proportions of concentrates (DeGregorio et al., 1982) are included in the diet. The higher intestinal digestibility of fibre fractions in diet $U$ than in diets $R$ and $F$ in experiment II may have been caused by the greater amount of fibre which did not undergo degradation in the rumen. In spite of the similar ruminal 
digestibility of NDF, ADF and cellulose of diets $\mathrm{U}$ and $\mathrm{C}$, the digestibility of these fractions in the intestines was significantly higher in diet $U$ than $C$. The lower digestibility of the fibre fractions of diet $\mathrm{C}$ could be associated with the lower level of ammonia nitrogen in the ileal contents. Hecker (1971) and Engelhardt and Hinderer (1976) demonstrated that the amount of urea passing to the large intestine depends on the blood urea concentration. Addition of non-protein nitrogenous compounds or protein easily degradable in the rumen to diets increases the rumen $\mathrm{N}-\mathrm{NH}_{3}$ concentration and thus a rise of urea concentration in the blood. This causes increased urea secretion to the lumen of the large intestine (Żebrowska and Kowalczyk, 1991), which is a nitrogen source for bacteria and increases their activity.

\section{Whole tract digestion}

The overall digestibility of nutrients of diets $\mathrm{R}, \mathrm{F}$ and $\mathrm{U}$, containing $13.5 \%$ protein, was significantly higher than of diet $C$ with $9.4 \%$ crude protein in DM (experiment II), is in agreement with the results of other experiments in which diets with various protein levels were fed (Chomyszyn et al., 1973; Kropp et al., 1977a; Goetsch et al., 1984). In an experiment carried out on wethers (Chomyszyn et al., 1973) the digestibility of the nutrients of diets containing ammonia-treated ( $15.1 \%$ crude protein in DM) or untreated DWM, supplemented with a protein-substitute concentrate $(16.1 \%$ crude protein in DM) or rapeseed oilmeal $(15.8 \%$ crude protein in $\mathrm{DM})$, was higher than in a diet containing only DWM (8.4\% CP in DM). Antoniewicz et al. (1981) similarly demonstrated the higher digestibility of DM, OM and crude fibre in diets containing DWM supplemented with urea (from 10.6 to $15.2 \%$ crude protein) than in non-supplemented diets $(8.5 \%$ crude protein in the diet).

The lack of differences in whole tract digestibility of DM and OM in diets differing in their nitrogen source is in agreement with the results of other studies in which isonitrogenous diets containing various protein sources were used (Chomyszyn et al., 1973; Garret et al., 1987; Zerbini et al., 1988; McCarthy et al., 1989; Seoane et al., 1990). In experiments on steers, Kropp et al. (1977b) showed that DM and OM digestibility decreased in diets in which 0 do $75 \%$ of soya bean meal nitrogen was replaced by urea nitrogen. In spite of the lack of differences in OM digestibility, Firkins et al. (1986) found lower NDF digestibility in the whole digestive tract of steers fed a diet containing maize gluten, with protein more rapidly degraded in the rumen, than when dried distiller's grain with slow protein degradation was used. Little et al. (1963), in spite of a lack of differences in DM and $\mathrm{OM}$ digestibilities, also found higher digestibility of cellulose when feeding semi-synthetic isoprotein diets $(8.6 \% \mathrm{CP})$ containing soya bean meal than when maize gluten was used. 


\section{CONCLUSIONS}

The results of these studies indicate that the nitrogen sources did not affect the whole tract digestibility of fibre fractions in sheep, but did, however, influence the digestibility of the fibre fractions in the particular parts of the digestive tract. It was not found that the differences of the fibre fractions digestibility were associated with the different rate of protein degradation in the rumen. It was found, however, that when urea was included in the diet, the ruminal digestibility of fibre fractions was lower and its intestinal digestibility higher than when other protein sources were used.

\section{REFERENCES}

Alvarez F., Dixon R.M., Preston T.P., 1984. Minimum rumen ammonia requirements for rumen digestion of $\mathrm{NaOH}$ treated maize cobs and Pennisetum purpureum. Trop. Anim. Prod. 9, 299-310

Andries J.I., Buysse F.X., De Brabander D.L., Cottyn B.G., 1987. Isoacids in ruminant nutrition: their role in ruminal and intermediary metabolism and possible influences on performances - a review. Anim. Feed Sci. Tech. 18, 169-180

Antoniewicz A., Ryś R., Skraba B., Gawlik Z., 1981. Wpływ fizycznej formy suszu z całych roślin kukurydzy oraz zawartości mocznika $w$ dawce na strawność, wykorzystanie składników pokarmowych i przebieg procesów trawiennych w żwaczu u owiec. Rocz. Nauk Zoot. 8, $193-207$

Beever D.E., Coelho da Silva J.F., Prescott J.H.D., Armstrong D.G., 1972. The effect in sheep of physical form and stage of growth on sites of digestion of a dried grass. I. Sites of digestion of organic matter, energy and carbohydrate. Br. J. Nutr. 28, 347-356

Chomyszyn M., Kużdowicz. M., Kowalczyk J., Orzeszko E., Tomerska H., Ziołecki A., 1973. Wartość pokarmowa suszu kukurydzianego (cała roślina) w żywieniu jagniąt. Rocz. Nauk. rol., Ser. B. $94,17-33$

Conway E.J., 1954. Microdiffusion analysis and volumetric error. Crosby Lockwood, London

Coppock C.E., Peplowski M.A., Lake G.B., 1976. Effect of urea form and method of feeding on rumen ammonia concentration. J. Dairy Sci. 59,1152-1156

Corbett J.L., Greenhalgh J.F.D., McDonald I., Florence E., 1960. Exrection of chromium sesquioxide as a component of paper to sheep. Br. J. Nutr. 14, 289-299

DeGregorio R.M., Tucker R.E., Mitchell, Jr. G.M., Gill W.W., 1982. Carbohydrate fermentation in the large intestine of lambs. J. Anim. Sci. 54, 855-862

Engelhardt W., Hinderer S., 1976. Transfer of blood urea into the goat colon. Tracer studies on non-protein nitrogen in ruminants. III Atomic Energy Agency, Vienna, 57-58

Fattet I.M., Ørskov E.R., 1984. Dietas ricas en concentrados. Effecto de la fuente de nitrogeno, del bicarbonato y del consumo, sobre la digestion del heno. Rev. Agr. Prod. Anim. 4, 1-11

Firkins J.L., Berger L.L., Merchen N.R., Fahey, Jr., G.C., 1984. Effects of forage particle size, level of feed intake and supplemental protein degradability on microbial protein synthesis and site of nutrient digestion in steers. J. Anim. Sci. 62, 1081- 1094

Garret J.E., Goodrich R.D., Meiske J.C., Stern M.D., 1987. Influence of supplemental nitrogen source on digestion of nitrogen, dry matter and organic matter and on in vivo rate of ruminal protein degradation. J. Anim. Sci. 64, 1801-1812

Goetsch A.L., Owens F.N., Funk M.A., 1984. Effect of nitrogen source on site of digestion in dairy cows and in semi-continuous rumen cultures. Nutr. Rep. Int. 30, 881-891

Ha J.K., Kennelly J.J., Berzins R., 1986. Effect of dietary nitrogen sources on microbial protein synthesis, dietary protein degradation and nutrient digestion in steers. Anim. Feed Sci. Tech. 14, $117-126$ 
Hecker J.F., 1971. Metabolism of nitrogenous compounds in the large intestine of the sheep. Br. J. Nutr. 25, 85-95

Hoover W.H., 1978. Digestion and absorption in the hindgut of ruminants. J. Anim. Sci. 46, $1789-1799$

Hoover W.H., Kincaid C.R., Varga G.A., Thayne W.V., Junkins Jr., L.L., 1984. Effects of solids and liquids flows on fermentation in continuous cultures. IV. $\mathrm{pH}$ and dilution rate. J. Anim. Sci. 58, $692-699$

Hume I.D., 1970. Synthesis of microbial protein in the rumen. II. A response to higher volatile fatty acids. Aust. J. Agric. Res. 21, 297-304 •

Kimura F.T., Miller V.L., 1957. Improved determination of chromic oxide in cow feed and feces. Arg. Food Chem. 5, 3, 216

Kowalczyk J., Otwinowska A., Jaczewska A., Królikowska K., Rusiński W., Czachor J., Benicewicz B., 1983. Otrzymywanie, właściwości i przydatność w żywieniu bydła bialkozastępczego preparatu jęczmienno-mocznikowego. Rocz. Nauk rol., Ser. B. 101, 4, 37-48

Kropp J.R., Johnson R.R., Males J.R., Owens F.N., 1977a. Microbial protein synthesis with low roughage rations: level and source of nitrogen. J. Anim. Sci. 45, 844-854

Kropp J.R., Johnson R.R., Males J.R., Owens F.N., 1977b. Microbial protein synthesis with low roughage rations: isonitrogenous substitution of urea for soybean meal. J. Anim. Sci. 45, $837-843$

Little C.O., Burroughs W., Woods W., 1963. Nutritional significance of soluble nitrogen in dietary proteins. J. Anim. Sci. 22, 358-363

Madsen J., Hvelplund T., 1988. The influence of different protein supply and feeding level on $\mathrm{pH}$, ammonia concentration and microbial protein synthesis in the rumen of cows. Acta Agric. Scand. 38, $115-125$

Maeng W.J., Van Nevel C.J., Baldwin R.L., Morris J.G., 1976. Rumen microbial growth rates and yields: effect of amino acids and protein. J. Dairy Sci. 59, 68-79

McAllan A.B., 1991. Carbohydrate and nitrogen metabolism in the forestomach of steers given untreated or ammonia treated barley straw diets supplemented with urea or urea plus fish meal. Anim. Feed Sci. Tech. 33, 195-208

McAllan A.B., Griffith E.S., 1987. The effects of different sources of nitrogen supplementation on the digestion of fibre components in the rumen of steers. Anim. Feed Sci. Tech. 17, 65-73

McAllan A.B., Smith R.H., 1983. Factors influencing the digestion of dietary carbohydrates between mouth and abomasum of steers. Br. J. Nutr. 50, 445-454

McCarthy Jr., R.D., Klusmeyer T.H., Vicini J.L., Clark J.H., Nelson D.R., 1989. Effects of source of protein and carbohydrate on ruminal fermentation and passage of nutrients to the small intestine of lactating cows. J. Dairy Sci. 72, 2002-2016

Mehrez A.Z., Ørskov E.R., 1977. A study of the artificial fibre bag technique for determining the digestibility of foods in the rumen. J. agric. Sci., Camb. 88, 645-650

Mould F.L., Orskov E.R., Mann S.O., 1983/1984. Associative effects of mixed feeds. I. Effects of type and level of supplementation and the influence of the rumen fluid $\mathrm{pH}$ on celulolysis in vivo and dry matter digestion of various roughages. Anim. Feed Sci. Tech. 10, 15-30

Oldham J.D., Broster W.H., Napper D.J., Smith T., 1979. Predicted and measured performance of Friesien cows fed on rations calculated to differ in rumen degradable protein and undegraded protein. Proc. Nutr. Soc. 38, 128A

Orskov E.R., McDonald I., 1979. The estimation of protein degradability in the rumen from incubation measurements weighted according to rate of passage. J. agric. Sci., Camb. 92, $499-503$

Robinson P.H., Sniffen C.J., 1983. Rumen and whole tract digestion as affected by intake of C-4 and C-5 acids. J. Dairy Sci. 66, Suppl. 1, 272

Roffler R.E., Schwab C.G., Satter L.D., 1976. Relationship between ruminal ammonia and nonprotein nitrogen utilization by ruminants. III. Influence of intraruminal urea infusion on ruminal ammonia concentration. J. Dairy Sci. 59, 80-84

Satter L.D., Slyter L.L., 1974. Effect of ammonia on rumen microbial protein production in vitro. Br. J. Nutr. 32, $199-208$ 
Seoane J.R., Christen A.-M., Dion S., 1990. Intake and digestibility in steers fed grass hay supplemented with corn or barley and fish meal or soybean meal. Can. J. Anim. Sci. 70, 921 - 926

Thomsen K.V., 1985. The specific nitrogen requirements of rumen microorganisms. Acta Agric. Scand. 25, Suppl. 125-131

Thomson D.J., Beever D.E., Coelho da Silva J.F., Armstrong D.G., 1969. Sites of digestion in sheep of a dried lucerne fed in three different physical forms. Proc. Nutr. Soc. 28, 24A-25A

Thomson D.J., Beever D.E., Coelho da Silva J.F., Armstrong D.G., 1972. The effect in sheep of physical form on sites of digestion of a dried lucerne diet. 1. Sites of organic matter, energy and carbohydrate digestion. Br. J. Nutr. 28, 31-41

Van Soest P.J., 1973. Colaborative study of acid detergent fibre and lignin. AOAC 56, 781-784

Van Soest P.J., Wine R.H., 1967. Use of detergents in the analysis of fibrous feeds. IV. Determination of plant cell wall constituents. AOAC 50,50-55

Zerbini E., Polan C.E., Herbein J.H., 1988. Effect of dietary soybean meal and fish meal on protein digesta flow in Holstein cows during early and midlactation. J. Dairy Sci. 71, 1248-1258

Ziołecki A., Kwiatkowska E., 1973. Gas chromatography of $\mathrm{C}_{1}$ to $\mathrm{C}_{5}$ fatty acid in rumen fluid and fermentation media. J. Chromatogr. 80, 250-254

Żebrowska T., Kowalczyk J., 1991. Nitrogen secretion into isolated loops in the small intestine in conscious sheep. J. Anim. Physiol. a. Anim. Nutr. 65, 133-139

\section{STRESZCZENIE}

\section{Wpływ różnych źródel azotu na strawność frakcji włókna u owiec}

Przeprowadzono trzy doświadczenia na owcach, w których badano tempo rozkładu suchej masy i frakcji włókna suszu z całych roślin kukurydzy metodą woreczków nylonowych (doświadczenie I), strawność badanych składników pokarmowych dawek w calym przewodzie pokarmowym (doświadczenie II i III) oraz jego poszczególnych odcinkach (doświadczenie II). Zwierzęta żywiono dawkami składającymi się z suszu z całych roślin kukurydzy z dodatkiem śruty rzepakowej (R), mączki rybnej (F), preparatu jęczmienno-mocznikowego (U) lub dawką kontrolną, składającą się z samego suszu (C). Dawki R, F i U były izoazotowe i izoenergetyczne. Źródło azotu w dawkach nie wpłynęło na wielkość rozkładu frakcji włókna suszu z kukurydzy in sacco w żwaczu (doświadczenie I), stwierdzono natomiast większą strawność w żwaczu włókna surowego, NDF, ADF i celulozy dawek R i F niż U i C (doświadczenie II). Strawność frakcji włókna w jelitach i jej procentowy udział w strawności w całym przewodzie pokarmowym był większy przy skarmianiu dawki z mocznikiem niż pozostałych dawek. Strawność frakcji włókna w całym przewodzie pokarmowym nie zależała od źródła białka w dawce (doświadczenie II i III), stwierdzono natomiast istotnie mniejszą ich strawność przy skarmianiu dawki $\mathrm{C}$ niż dawek $\mathrm{R}, \mathrm{F}, \mathrm{U}$. 